\title{
THE FLAG OF IMAGINATION: PERU'S NEW REFORM ON LEGAL CAPACITY FOR PERSONS WITH INTELLECTUAL AND PSYCHOSOCIAL DISABILITIES AND THE NEED FOR NEW UNDERSTANDINGS IN PRIVATE LAW
}

\author{
RENATO ANTONIO CONSTANTINO CAYCHO*,1
}

\begin{abstract}
This paper analyzes the recent reform regarding the legal capacity of persons with disabilities in Peru. It provides a domestic legal and judicial context in which the reform was adopted. Following this, the paper aims to analyze the reform's conformity with article 12 of the Convention on the rights of persons with disabilities, noting that the current regulation is only partially CRPD compliant. The current design of judicially designated supporters can be understood as valid under specific interpretations of Article 12, while the design of safeguards does not comply with such standard. The paper addresses the impact of legal capacity reform in traditional private law theory of the juridical act. Currently, the Peruvian system does not provide clear or accurate standards to respond to this problem. The paper shines a light on the need to rethink multiple concepts of private law in order to make legal capacity reform fully operational.
\end{abstract}

Keywords: Human rights; disability studies; Peruvian civil law; legal capacity reform; supported decisionmaking; UN Convention on the rights of persons with disabilities.

Summary: 1. Introduction. 2. Previous developments Regarding legal capacity of persons with Disabilities in international human Rights law and Peruvian Law. 2.1. A brief reference to legal capacity in international human rights law. 2.2. A brief reference to the legal context in Peru. 2.3. Legislative developments. 2.4. Judicial developments. 3. Legal capacity in the Reform. 4. Support in the Reform. 5. The exceptional case of uudicially designated supporters. 6. Safeguards in the Reform. 7. The Reform

* Conflict of Interest declaration: Renato Constantino participated in civil society consultations of legal capacity reform in Peru. During 2017, he was one of the leaders of lobbying efforts in favor of Proposal 872/2016, a bill that would have reformed legal capacity law in Peru.

${ }^{1}$ Renato Antonio Constantino Caycho is a Peruvian Lawyer. He has JD (equivalent) and a M.A. in Human Rights from Pontificia Universidad Católica del Perú. He also holds an LLM in International Legal Studies from American University - Washington College of Law, where he was Open Society Foundations Disability Rights Fellow. He is currently a Full-time professor at Pontificia Universidad Católica del Perú's Department of Law and is a member of the Interdisciplinary Research Group in Disability - GRIDIS PUCP (renato.constantino@pucp.pe).

Many of the ideas presented here come from seeing my mother exercise her legal capacity after having a brain injury in 2018. She inspires me every day.

Different versions of this document were presented at the Society for Disability Studies Multiple Perspectives on Access, Inclusion, and Disability Conference at the Ohio State University (2019) and at the Essex Autonomy Project Summer School at University of Essex (2019). A few of the ideas presented here were also mentioned in Spanish at: Bregaglio Lazarte, R. A., \& Constantino Caycho, R. A. (2020). Un modelo para armar: La regulación de la capacidad jurídica de las personas con discapacidad en el Perú a partir del Decreto Legislativo 1384. Revista Latinoamericana en Discapacidad, Sociedad y Derechos Humanos, 4, 28. The text has received generous and insightful comments from Robert Dinerstein, Wayne Martin, Sándor Gurbai, María Gómez, Polona Cuk, Renata Bregaglio and Agustina Palacios. Usual caveats apply. A special note of thanks to Paula Camino for her research assistance. 
in Current Private Law Theory. 7.1. The Juridical Act in Private Law. 7.2. Some examples of the interaction of the doctrine of juridical act and Article 12. 7.2.1. Error. 7.2.2. Conflict of interest. 7.2.3. Undue influence. 7.3. Preliminary conclusions. 8. ConCLusions

\section{INTRODUCTION}

Implementation of Article 12 of the Convention of the Rights of Persons with Disabilities (CRPD) is one of the most critical issues in disability rights nowadays. It has been quite difficult for many to grasp its implementation. That is why any reform on the matter gets immediate attention from the disability rights scholarly community. Peru's Civil Code Reform has been praised as the most CRPD-compliant normative modification regarding legal capacity of people with disabilities by experts (Minkowitz, 2018), international organizations (Inter-American Commission on Human Rights, 2018) and in academia (Martinez Pujalte, 2019, p. 4).

Peru's traditional disability-based substitute decision-making regime was completely eliminated via Legislative Decree 1384, published on September 4, 2018. This article will analyze the Reform's legal text to assess its compliance with the CRPD. ${ }^{2}$ In doing so, I will try to assess the challenges that remain in order to achieve a full recognition of legal capacity of persons with disabilities in Peru. I will also assess the impact the Reform has had on the concept of free will and how this affects the basic tenets of Private Law.

Therefore, this paper will have the following structure: (i) a reference to previous developments in Peruvian law, followed by an analysis of the most important reforms regarding: (ii) legal capacity; (iii) support; and (iv) safeguards. After that, I will analyze (v) how the Reform interacts with the concept of free will stated in the theory of juridical acts. Next, I will address the issues that were not modified by the Reform and that are related to the full recognition of the legal capacity of persons with disabilities. Finally, I will present some conclusions and final comments.

\section{Previous deVelopments Regarding legal CaPaCity OF Persons With disabilities in international human rights law and Peruvian Law}

In this section I will provide some context for the reader on the Peruvian Civil Code Reform and the efforts from the State and civil society that allowed for this Reform.

\footnotetext{
${ }^{2}$ For the most part, I will use SODIS' translation of the text of the Reform. I believe it is a great translation, but I have some reservations. For example, in article 221, the translation uses "voidability" for the term "nulidad". I prefer the use of "voidness" because it shows that the act never existed. "Voidability" would be more like "anulabilidad", a Civil Law term that indicates that an act could be void but also confirmed. The translation can be found here: http://www.chrusp.org/file/340835/Legislative_Decree_No_1384 Peruvian_legal_capacity_reform_docx
} 


\subsection{A brief reference to legal capacity in international human rights law.}

Article 12 CRPD is entitled "Equal recognition before the law" and it has 5 sections: legal personhood (passive capacity), legal capacity (capacity to act), supports, safeguards and access to property and financial services. This means that States "shall recognize that persons with disabilities enjoy legal capacity on an equal basis with others in all aspects of life" (Article 12.2). According to the CRPD Committee's General Comment 1, legal capacity "recognizes the person as an agent who can perform acts with legal effect" (2014, para. 16). Therefore "States must holistically examine all areas of law to ensure that the right of persons with disabilities to legal capacity is not restricted on an unequal basis with others" (CRPD Committee, 2014, para. 7). This does not mean that any restrictions are forbidden. It means that they cannot be based on a disability. Then, disability-neutral ${ }^{3}$ reasons such as "bankruptcy or criminal conviction" are allowed (CRPD Committee, 2014, para. 32) as long as they do not violate other human rights.

The text of Article 12 made it clear that disability could not be a reason to deny legal capacity. However, the understanding of this statement was not clear for everyone. Many argued that in certain cases, when the person with a disability does not understand or cannot act on that understanding, there should be some space for disability-based substitute decision-making (Del Villar, 2015; Dawson, 2015). However, the Committee decided that the functional approach "is flawed for two key reasons: (a) it is discriminatorily applied to people with disabilities; and (b) it presumes to be able to accurately assess the inner-workings of the human mind and, when the person does not pass the assessment, it then denies him or her a core human right - the right to equal recognition before the law" (CRPD Committee, 2014, para. 15). This debate, as well as others, will inform my analysis throughout the paper.

\subsection{A brief reference to the legal context in Peru}

Peru is a continental law jurisdiction. This means that judges are not as open to innovation as they might be in common law jurisdictions. ${ }^{4}$ Consequently, reforms usually require new legislation, as judges are not able to modify legislation, and are not too keen to interpret existing legislation in a way that would disrupt the status quo either, even when doing so may be justified. This is relevant in regard to the Reform on legal capacity, since CRPD was automatically Law in Peru since 2008. Even though CRPD was automatically Law in Peru and had priority over acts and statutes, few judges, if any, were willing to apply Article 12 before the Civil Code Reform.

Another relevant issue is access to information regarding the application of Article 12. Most of the literature on Article 12 (Bhailís, Clíona and Flynn, 2017) and its implementation (Dhanda, 2017, p. 88) has been written in English, and has focused on

\footnotetext{
${ }^{3}$ It is important to mention that the concept of 'disability -neutral' does not have a widely understood meaning. For a proposal see (Flynn \& Arstein-Kerslake, 2017) and for a criticism see (Minkowitz, 2017, pp. 81-84)

${ }^{4}$ For a comparison between legal systems, see David, 1978.
} 
the experience of First World countries (Dhanda, 2017, p. 88). As Dhanda has stated, this usually makes it difficult for developing countries to vie for reform, because the usual excuse put forward by legislators is that "the resources available in First World countries are not available" for our countries, and thus reforms cannot be implemented (Dhanda, 2017, p. 88).

Nevertheless, Peru managed to implement its reform. Although the reform caught most people by surprise, it did not happen overnight - we can track a series of actions that led up to its approval (International Disability Alliance, 2017, pp. 17-20). Peru ratified the CRPD in 2008. During the State's first appearance before the UN CRPD Committee, the Committee stated that Peru's legislation was not in conformity with Article 12 (CRPD Committee, 2012, para. 24). This was not an unusual conclusion for the Committee, as few - if any - legislations around the world actually allow for full supported decision making. In fact, it is important to note that the Committee has not found any national legislation to be fully CRPD compliant (Dinerstein, Grewal and Martinis, 2016, p. 448). At the time, Peru's legislation allowed for substitute decision - making. It also discriminated against "deaf-mute, blind-deaf and blind-mute persons, as well as mentally handicapped persons and those suffering from mental deterioration" (CRPD Committee, 2012, para. 26). Since then, there have been several changes regarding legal capacity of persons with disabilities, both in the legislative framework and in judicial practice.

\subsection{Legislative developments}

Prior to this reform, there were some attempts to recognize the legal capacity of persons with disabilities. The Person with Disabilities Act 2012, Law 29973, ${ }^{5}$ recognized the legal capacity of persons with disabilities. However, the Act did not modify the Civil Code, so this recognition did not have an impact on the recognition of legal capacity in the system. ${ }^{6}$ As the current UN Special Rapporteur on the Rights of Persons with Disabilities has stated, it had more of a declarative value (Devandas, 2017, para. 40). Thus, as the Act had not removed most legal restrictions in hierarchically superior norms that denied legal capacity to persons with mental disabilities, it did not effectively align Peruvian legislation with article 12 of the CRPD. It did, however, have a limited effect, insofar as it eliminated provisions against the deaf-mute, blind-deaf and blind-mute persons. ${ }^{7}$

\footnotetext{
${ }^{5}$ Enacted by Law 29973, The Person with Disabilities Act, published on 24 December 2012.

${ }^{6}$ In fact, the Person with Disabilities Act 2012, 29973, stated that: “Article 9 - Equal recognition as persons before the law 9.1 Persons with disabilities enjoy legal capacity on an equal basis with others in all aspects of life. The Civil Code regulates the support systems and reasonable accommodations they require for decision making. 39.2 The State ensures persons with disabilities their right to own property, to inherit, to access and freely contract for insurance, bank loans, mortgages and other forms of financial credits, on an equal basis with others. Likewise, it ensures their right to marry and to freely decide on the exercise of their sexuality and fertility." The translation comes from this website: http://www.internationaldisabilityalliance. org/sites/default/files/documents/peru_general_law_on_persons_with_disabilities.english.pdf

7 "Mute" is considered an offensive term for deaf and hard of hearing persons. However, it is the literal term used by the previous legislation.
} 
Despite falling short of proper reform, the Act did create a Special Committee for the reform of the Civil Code 1984, which drafted a bill on the matter. ${ }^{8}$ Civil society, academia and public officers were all represented in this Committee. Due to time constraints, the bill did not address every aspect covered by Article 12 and thus would have failed to implement a proper, Article 12-complaint, Civil Code Reform. Ultimately, the bill did not pass, because the congressperson could not argue for the text when confronted against criticism and doubts. It did, however, serve as the basis for Proposal 872/2016, bill drafted by civil society that received multi-party support and it is safe to say that this last document was the main input for the Legislative Decree $1384 .{ }^{9}$

Reforming the Civil Code 1984 has been a long and tedious process. Most congresspersons and their advisors were not fully aware of the implications of Article 12. Many of them wanted to improve conditions for persons with disabilities but doubted that recognizing full legal capacity was the correct path to doing so. Civil society, on the other hand, made several unsuccessful pushes for the Proposal's approval. Most Private Law scholars were absent from the debate and the majority of those who did participate, opposed the Proposal (Bolaños Salazar, 2018, pp. 124-128). I believe that their opposition came from an unwillingness to challenge any concept of Private Law like discernment. One of them actually wrote, during another attempt to modify the Civil Code: "At this point of my life, what I do not understand is wrong” (Castillo Freyre, 2005, p. 38).

During this time, there was a desire from government to change things, but no clear guide on how to proceed. The Executive Branch's Legislative Decree on additional simplification measures for administrative affairs 2017, Decree 1310 is proof of this. ${ }^{10}$ The Decree aimed to facilitate the process through which older persons could access their retirement pensions. At the time, as guardianship laws were still in place, financial institutions would demand a guardianship ruling before granting a person access to their pension. As the court procedure was long and often expensive, the Decree allowed for a notary procedure to appoint a guardian, applicable only to these cases.

Four days after the Civil Code's Reform, the Decree was modified via Legislative Decree for the inclusion of persons with disabilities 2018, Decree 1417, which eliminated all references to guardianship and changed them for references to supports. ${ }^{11}$ However, the

\footnotetext{
${ }^{8}$ The Committee members were: Congresspersons Jhon Reynaga and Rosa Mavila; President of the National Council for the Integration of Persons with Disabilities (CONADIS); representative of the Judicial Branch, representative of the Pontificia Universidad Católica del Perú School of Law, representative of the Office of the Ombudsperson, representative of the National Registry of Identification and Civil Status (RENIEC); and three representatives of civil society from Alamo Perú (organization of persons with psychosocial disabilities), Sociedad Peruana de Síndrome Down (organization of relatives of persons with Down Syndrome) and Sociedad y Discapacidad - SODIS, a human rights organization specialized on the rights of persons with disabilities.

${ }^{9}$ In the Peruvian legal framework, a legislative decree is an act of the Executive Branch with the same power and validity of an Act of Congress, since it is developed under the explicit permission of the Parliament.

${ }^{10}$ Legislative Decree 1310 on additional simplification measures for administrative affairs, published on December $30^{\text {th }} 2018$.

${ }^{11}$ Legislative Decree for the inclusion of persons with disabilities, published on September $13^{\text {th }} 2018$.
} 
Decree now establishes a procedure for appointing supports, and safeguard measures, that are applicable only to these cases and differ from the general supported decision-making regime.

Parallel to this, the Executive Branch decided to recognize "supports" within a public policy that awarded non-contributive pensions to persons with severe disabilities living in poverty. ${ }^{12}$ As I mentioned prior, most institutions required a person with a disability to provide a guardianship ruling in order to access a pension. Since most people who qualified for this pension live in rural areas, it was essentially impossible for them to initiate a guardianship procedure before a judge or notary, due to the lack of accessible services. In light of this, the Ministry of Inclusion and Social Development stipulated that another person could receive the money, provided that he or she lived with the person with a disability and could later prove that the money was used for the care of the person with a disability, a measure that could be seen as safeguard. ${ }^{13}$ Although these persons could be construed as supports, this law established yet another form of support that, in this case, did not consider the will of the person with a disability. In conclusion, there were different and opposing measures regarding legal capacity before the Reform.

\subsection{Judicial developments}

There have also been some judicial cases that dealt with legal capacity prior to the Reform. At the highest level, the Constitutional Court has not properly understood the social model of disability and its implications until the Reform (Verano, Constantino and Bregaglio, 2018, p. 20). In 2009, in a case regarding the placement of a person with a disability in a care home by a guardian, ${ }^{14}$ the Constitutional Court argued that the protection of persons with disabilities does not mean that "persons who suffer mental disabilities lack a will or that their will has no value" (2009, para. 4). The Court also argued that "mental disability is not a synonym, prima facie, of an inability to make decisions. In the Court's view, although persons who suffer mental illnesses usually have difficulties to decide or to communicate such decisions, their will should be take into account because it is a manifestation of their self-determination and, on a fundamental level, of their dignity" (Constitutional Court, 2009, para. 6). However, in this same decision, the Court held that it should not be the guardian who decided whether to place the person in question in a care home or not, but a council formed by relatives of the person with a disability. The relatives would have to make a decision following a best-interest approach. This was held even

\footnotetext{
${ }^{12}$ This program is called "Contigo", which means, "With you". It was created via the Persons with Disability Act 2012, Law 29973. The article in question states: "Article 59. Noncontributory pensions for severe disabilities Persons with severe disabilities living in poverty, in accordance to the criteria of the Household Targeting System (SISFOH) and who do not have a pension or income from public or private sectors, receive a noncontributory pension from the State. The health directorates will provide the certificate of severe disability and CONADIS will register them. The regulations establish the requirements and conditions to progressively access this benefit." Translation retrieved from: http://www.internationaldisabilityalliance. org/sites/default/files/documents/peru_general_law_on_persons_with_disabilities.english.pdf

13 The directive is available at: $\overline{h t t p: / / w w w . j u n t o s . g o b . p e / m o d u l o s / a u t o r i z a c i o n e s / n o r m a t i v a / ~}$ PROCEDIMIENTO_DE_AUTORIZACION_DE_COBRO.pdf. Published on May $2^{\text {nd }} 2018$.

${ }^{14}$ Constitutional Court of Peru. Decision on case $\mathrm{N}^{\circ} 2313-2009-\mathrm{HC} / \mathrm{TC}$. September 24 ${ }^{\text {th }}$ 2009, para. 4. Available at: https://tc.gob.pe/jurisprudencia/2009/02313-2009-HC.pdf
} 
though the person with a disability in question had expressed her desire to leave the care home, essentially ignoring that person's will. ${ }^{15}$ At no point of the discussion did the Court make any mention to the obligation that stems from Article 12, or the CRPD. Not only did the Court ignore Article 12, but it openly opted for a decision that opposed the article's provisions. Only recently did the Constitutional Court ${ }^{16}$ recognize the importance of legal capacity of persons with disabilities, in consonance with Legislative Decree 1384 (2014).

Nevertheless, at the trial court level, there have been some notable advances. In 2014, Judge Jorge Ramírez Niño de Guzmán ruled that a guardianship process against a person with psychosocial disability had serious violations of due process and thus nullified the process. ${ }^{17}$ However, this decision was not justified on the basis of CRPD obligations. The judge arrived at his ruling mainly because during the initial guardianship process, the person with disability had not been allowed to choose his own lawyer or provide proof or testimony. The decision was confirmed on appeal in 2018. ${ }^{18}$

In 2015, Judge Edwin Béjar - who happens to be the first and only blind judge in Peru - argued that the guardianship regime was not legal, as it contradicted Article 12 of the CRPD. ${ }^{19}$ Therefore, he ruled that a guardian should not be appointed to two brothers with intellectual disabilities, and ordered the National Office of Pensions not to require a guardianship ruling in order to award the brothers their pension, even though before the Reform, providing a guardianship decision to access a pension was a statutory requirement. The judgment also created a "temporary supported decision-making system" specifically for the two brothers. Their mother, sister, and the court's social services team: a coordinator, psychiatrist, psychologist and social worker were all parties in this system. Additionally, judge Béjar provided an easy-to-read version of the decision. It is important to note that requiring a guardianship ruling in order to award a pension is now expressly prohibited by Legislative Decree $1384 .{ }^{20}$ However, the decision was overturned by the Superior Court in 2015. ${ }^{21}$ After Judge Béjar tried the case once again and arrived at the same ruling, the ruling was declared null by the Supreme Court in $2017 .{ }^{22}$

\footnotetext{
${ }^{15}$ According to Article 619 of the Civil Code prior to the Reform, the Family Council looks out for the interests of incapable adults without parents.

${ }^{16}$ Constitutional Court of Peru. Decision on case $N^{\circ}$ 0194-2014-HC/TC, April 30 ${ }^{\text {th }} 2019$. Available at: https://tc.gob.pe/jurisprudencia/2019/00194-2014-HC.pdf

${ }^{17}$ Second Constitutional Court of Lima. Decision in case N² 25158- 2013-0-1801-JR-CI-02.

${ }^{18}$ Third Civil Trial Court of Lima. Decision in in case $\mathrm{N}^{\circ}$ 25158-2013-0-1801-JR-CI-02. Retrieved from: https://static.legis.pe/wp-content/uploads/2018/06/Sala-confirma-capacidad-jur\%C3\%ADdica-de-personacon-exquizofrenia-Legis.pe_.pdf

${ }^{19}$ Third Family Court of Cusco. Decision in case N 01305-2012-0-1001-JR-FC-03. Available at: http:// www.gacetajuridica.com.pe/envios-laley/SENTENCIA-CUSCO1.pdf

20 The second transitional complementary provision is as follows: "Elimination of the requirement of interdiction.- All public and/or private entities adapt their administrative procedures, under their responsibility, within a period not greater than one hundred and twenty (120) calendar days, counting from the day following the publication of the Decree in the Official Gazette El Peruano." (Own translation).

${ }^{21}$ Civil Chamber of the Superior Court of Justice of Cusco. Decision No 38 in case N ${ }^{\circ} 01305-2012-0-1001-J R-$ FC-03. Available at: www.pucp.edu.pe/6yXXyn

${ }^{22}$ Permanente Constitutional and Social Chamber of the Supreme Court of Justice. Decision in file $\mathrm{N}^{\circ} 1833$ 2017. Available at: https://static.legis.pe/wp-content/uploads/2019/01/Exp.-1833-2017-Cusco-Legis.pe_.pdf
} 


\section{Legal CAPACITY IN THE Reform}

The reform was ultimately passed in September of 2018 via Legislative Decree 1384. This decree modified and repealed norms in the Civil Code 1984 and the Code of Civil Procedure 1993 to introduce a supported decision-making system in Peru. Fundamentally, the Decree eliminated provisions in the articles 43 and 44 of the Civil Code 1984 that allowed for substituted decision-making regimes (via guardianship rulings) in the cases of persons with mental disabilities. ${ }^{23}$ The Civil Code 1984 was reformed to recognize full legal capacity to persons with disabilities who, except for certain cases, can freely appoint supports and safeguards through judicial or notary procedures.

For those "difficult cases" referred to previously, the reformed Code establishes the possibility of "compulsory supports". That is to say that when a person cannot communicate their will, even after all efforts (including measures of accessibility and reasonable adjustments) to understand it have been exhausted, a judge can appoint supports and safeguards to protect or exercise the rights of said person, by request of any third party. According to the reformed Civil Code 1984, any natural or juridical person can be designated as a supporter, and supporters can be designated for specific acts, in the present or in the future. As I shall further explain in the following sections of this paper, the reform establishes a compulsory safeguard, and leaves open the possibility to create other safeguards.

The first issue the new law addresses the determination of persons who have legal capacity. The Legislative Decree eliminates any ground for guardianship based on disabilities. However, restrictions on legal capacity remain. Five sets of people will still be subject to guardianship: habitual drunkards, drug addicts, persons with criminal convictions, bad administrators and spendthrifts. While these sets of people were always subject to guardianship, the Legislative Decree added another ground: persons in a coma without a previously appointed supported decision-making system. In order to clarify some definitions, I will briefly state that bad administrators are those who have lost more than half of their assets due to bad administration, and prodigals are those who have spent most of their money so as to endanger their own existence or the ones dependent on them. The categories that have been removed are people who are "mentally retarded" 24 and "people with mental impairment that does not allow them to express their free will", both of which were directed towards persons with disabilities.

The multi-party Bill had proposed the elimination of all of restrictions on legal capacity. However, the Legislative Decree ultimately eliminated only those guardianships

\footnotetext{
${ }^{23}$ The Code referred to persons with intellectual and psychosocial disabilities as "mentally retarded", "incapable of discernment" and people with "mental deterioration that does not allow them to freely express their will".

24 "Retarded" is usually considered an insult to persons with intellectual disabilities. In United States, it may even amount to hate speech. On 2010, President Obama signed into law Pub. L. 111-256, usually known as Rosa's Law. Said statute substitutes the terms "intellectual disability" and "individual with intellectual disability" for "mental retardation" and "mentally retarded" in all federal health, education and labor policy statutes, due to the stigma associated to these terms. However, it is the exact translation of the term in Spanish.
} 
directly related to disability. ${ }^{25}$ This has been criticized because some of the remaining reasons could have an adverse impact on persons with disabilities. Persons with disabilities could have episodes of addiction that could lead others to classify them as "habitual drunkards" or a "drug addict". A person with disability who spends a lot of money or has a gambling addiction could also be classified as a "bad administrator" or a "spendthrift".

The next question that arises is whether people who currently have guardians, will automatically have legal capacity with the publication of the reform. During the Bill's negotiations, this was a highly discussed topic: is it really possible to restore legal capacity via a law? What happens if someone really needs a strong support that is very similar to a guardianship? The Decree decided to preserve existing guardianships. This probably has a lot to do with the disruptive effect that the total elimination of guardianships could have in the certainty of legal transactions. However, it is interesting to note that there currently are guardianships with no clear legal basis in Peru. As the people under guardianship age, these should naturally become extinct from the system. Also, the existing guardianships have been dealt with in two ways. The first path derives from Legislative Decree 1384 the Decree that implemented the reform. According to its norms, any party can request the reversal of the interdiction of persons with disabilities, issued prior to the entry into force of the Reform, to be substituted by the designation of supports and safeguards. ${ }^{26}$ The article allows for any party to request a reversal, not necessarily someone close to the person with a disability or someone with a legitimate interest.

Another interesting issue is the consequences of the reversal. Even though the logical consequence would have been the reversal of the guardianship, the Decree opted for the transformation of a guardianship regime into a supported decision-making regime. This means that guardianship will not be immediately overturned, but rather the person in question will have to go through a process designed to provide supports or safeguards. The Decree was not clear on what would happen if the person does not desire supports or safeguards. However, the Judiciary's Transition Rules 046-2019-CE-PJ ${ }^{27}$ state that the person has the right to reject supports and safeguards.

The second way to deal with current guardianships was proposed in 2019, through the Judiciary's Transition Rules 046-2019-CE-PJ. According to these rules, judges have the duty to promote the renewal of proceedings to revert or transform guardianship rulings

\footnotetext{
${ }^{25}$ The article in question reads as follows: "Article 564.- Persons subject to curatorship. The persons referred to in Article 44 paragraphs 4, 5, 6, 7 and 8 are subjected to curatorship." (Own translation).

${ }^{26}$ The second final supplementary provision reads as follows: "Second. Restoration of the capacity to act of the interdicted persons. Any person can request the reversal of the interdiction of persons with disabilities, issued prior to the entry into force of this law, by the designation of supports and safeguards." (Own translation).

${ }^{27}$ Article 3.2.d of the Administrative Resolution, published on February 12th 2019, reads as follows: "In case the person with disability indicates that he/she does not require supports, the legal capacity will be reinstituted, leaving the guardianship and the appointment of the guardian without effect and concluding the process." (Own translation).

Resolución Administrativa 046-2019-CE-PJ. Aprueban el "Reglamento de Transición al Sistema de Apoyos en Observancia al Modelo Social de la Discapacidad".
} 
or procedures. The transformation of a guardianship ruling or procedure into a procedure to designate supports can only happen with the person's consent, except in the cases of compulsory designation of supports. This Decree also deals with on-going guardianship processes. When it comes to these, judges are ordered to transform these to supports and safeguard designation processes if the person so wishes or cease proceedings if the person does not wish to appoint supports. ${ }^{28}$

In conclusion, even with the Reform, it is possible that some people with disabilities will remain under guardianship and that some will have guardianships imposed on them in the future for reasons that may have a disproportionate impact on persons with disabilities. It is critical to clearly assess the disproportionate impact of certain regulations on guardianship that are not directly related to disability. Another concern to address is the best solution for existing guardianships. The complete and immediate elimination may be a complicated objective. However, it will be interesting to see what replacements for guardianship will arise and whether a general response could be applicable to all (or most).

Another important aspect are liability rules regarding the supporter or supporters. The Civil Code 1984 now states that supporters are not directly liable for the acts of the person that receives the support. ${ }^{29}$ However, a person with a disability will be able to make a claim against their supports if they believe they have been ill advised on an issue. We will touch on the concept of "ill advised" in the following sections. Here, it is important to note that the referred article does not establish a standard under which supporters would be held liable.

The article regarding liability mentions the "intent or fault" standard, but only for the supporters of persons in coma. Therefore, there is no clear standard to evaluate whether a claim against a supporter would be valid in other cases. Would the "intent or fault" standard still be applicable? How should the standard be applied? Should the standard be objective and, therefore, based on a definite set of rules and principles applicable to all persons providing support? Or should it be subjective and, therefore, different supporters could be liable in different ways, accounting for their particular circumstances? In that case, for example, a lawyer providing support would have a different standard of liability from that of a person with no formal education. Judges in a diverse country like Peru should probably take into account the context and characteristics of a person before establishing any liability. Thus, I am in favor of a subjective approach in this matter.

\footnotetext{
${ }^{28}$ The transitional complementary provision reads as follows: "First.- Transition to the system of supports and safeguards: The Judge transforms the following processes into one of supports and safeguards: [...] b) Those ongoing proceedings of interdiction, initiated prior to the entry into force of this law. In these cases, the processing of the proceedings is suspended and the rules established in Chapter Four to Title II of the Fourth Section of Book III of the Civil Code apply. The Executive Council of the Judiciary establishes the rules and procedures necessary for the correct functioning of the transition to the system of support in mandatory compliance with the social model of disability." (Own translation)

${ }^{29}$ The article in question reads as follows: "Article 1976-A.- Responsibility of the person with support. The person who receives support is responsible for their decisions, including those made with such support, with the right to make a claim against them. Persons included in article 44 provision 9 are not responsible for decisions taken with judicially designated support that were carried out with intent or fault."
} 


\section{SUPPORT IN THE REFORM}

The term support in the context of supported decision-making can mean many things. ${ }^{30}$ It can mean accessibility measures for some people, or accommodations regarding time to decide. But it usually means mechanisms that help people with disabilities to arrive to a decision or to communicate such decision. For example, they can include: "formalized support for decision-making; shared or co-decision-making; appointing a representative to make decisions; and forms of advance planning such as advance directives and Ulysses directives" (Del Villar, 2015, p. 189).

In most cases, people will rely on supported decision making. Dinerstein defines this as:

"a series of relationships, practices, arrangements, and agreements, of more or less formality and intensity, designed to assist an individual with a disability to make and communicate to others decisions about the individual's life. Some of the above alternatives to guardianship could be part of a supported decision-making regime, though, to the extent they involve the individual with a disability identifying someone else as authorized to speak for him or her, they can move into a form of substituted decision-making (albeit one that is less restrictive of the individual's liberty than guardianship). A purer form of supported decision-making would rely on peer support (for example, ex-users of psychiatric services for people with psycho-social disabilities), community support networks and personal assistance, so-called natural supports (family, friends), or representatives (pursuant to a representation agreement) to speak with, rather than for, the individual with a disability" (Dinerstein, 2012, p. 10).

Thus, succinctly, supported decision making can help a person with disability to "(a) obtain and understand information, (b) evaluate the possible alternatives and consequences of a decision, (c) express and communicate a decision, and/or (d) implement a decision." (Devandas, 2017, para. 41).

Undoubtedly, one of the big triumphs of this Reform is the recognition of supports for the exercise of legal capacity. ${ }^{31}$ We must note that the definition of supports employed

\footnotetext{
${ }^{30}$ The text of article 12(3) reads as follows: "States Parties shall take appropriate measures to provide access by persons with disabilities to the support they may require in exercising their legal capacity".

${ }^{31}$ The text of article 659-B of the Peruvian Civil Code 1984 now reads as follows: "Supports are forms of assistance freely chosen by a person of legal age to facilitate the exercise of their rights, including support in communication, in the understanding of legal acts and their consequences, and the expression and interpretation of the will of the one who requires the support.

The support has no powers of representation except in cases where this is expressly established by decision of the person in need of support or by the judge in the case of Article 659-E.

When the support requires interpreting the will of the person who is being assisted, the criterion of the best interpretation of the will applies, taking into account the life trajectory of the person, previous expressions of will in similar contexts, the information provided by trusted people of the assisted person, the consideration of their preferences and any other consideration relevant to the specific case."
} 
in CRPD Committee's General Comment 1 was too broad and did not help States on how to legislate their implementation. The Peruvian Decree overcomes this problem by indicating that supports are "forms of assistance freely chosen by a person of legal age to facilitate the exercise of their rights, including support in communication, in the understanding of legal acts and their consequences, and the expression and interpretation of the will of the one who requires the support" (article 659-B). In this section we will try to provide some insight on how supports work within this Reform.

The Decree states that the role of a support "can fall on one or more natural persons, public institutions or non-profit legal entities, specialized both in the matter and duly registered" (article 659-C). This means that support can also be provided by an institution, given that it is a non-profit institution. It is both interesting and important that enterprises have not been allowed to offer "decision-making support services". It is not clear why this should not be possible, especially when Peruvian legislation, as I will explain later, has not developed provisions regarding conflicts of interest in this matter.

In accordance with CRPD Committee's General Comment 1, the Decree does not allow the imposition of supports in most cases (2014, para. 19). However, this may create some complex situations. What would happen if a person needs a support to understand certain contracts but does not want one? Should that person be entitled to the "dignity of risk" understanding? (Gooding, 2013, p. 435-436) That concept explains that persons with disabilities have to be allowed to make risky decisions because it is part of all human beings' dignity and self-realization. For these situations, I will provide some ideas about safeguards below.

\section{THE EXCEPTIONAL CASE OF JUDICIALLY DESIGNATED SUPPORTERS}

One of the strongest arguments against the Reform was based on the "difficult cases". This is how some people in the Parliament called persons with severe impairments that made understanding or communication almost impossible. For those cases, the Reform included Article 659-E. This article deals with persons who cannot express their will even "after having made real, considerable and pertinent efforts to obtain an expression of will from the person and having provided them with measures of accessibility and reasonable accommodations" (article 659-E, own translation). In those cases, any third party can petition a judge to designate supports. In these cases, unlike regular cases where the person with disability will make the decision, the judge will design and designate the supports. According to the Decree, this exceptional judicial designation can only be applied after the judge has "made real, considerable and pertinent efforts to obtain an expression of will from the person and having provided them with measures of accessibility and reasonable accommodations" (article 659-E, own translation). In selecting the supporter(s) the judge must take "into account the relationship of cohabitation, trust, friendship, care or kinship that exists between them and the person that requires support (article 659-E, own translation).

One valid question follows from this norm: can a "functional approach" test be justified in these situations, in order to know what accommodations or measures of 
accessibility a person would need? Asking this question does not ignore that the functional approach is not free of criticism. As Series has said, the approach may be arbitrary, invasive and, mainly, "will penalize those with impairments which affect their communication or interpersonal functioning, or those merely lacking self-confidence or trust in their capacity assessor" (Series, 2014). Therefore, it is important to engage and analyze the functionality of the person with disability, not to eliminate their legal capacity but to be certain of what kind of supports are most appropriate in each particular case.

One might argue that the person providing support for someone who does not communicate is, in practical terms, a 'substitute decision-making regime'. To respond to the argument, we have to assess where the judicially appointed support systems fall within the scope of the CRPD Committee's definition of substitute decision-making. The Committee's definition of substitute decision making incorporates three elements: (i) removal of legal capacity; (ii) the appointment of a substitute decision maker by a third party; or (iii) the decisions are made based on the "best interest" of the person instead of their will and preferences (2014, para. 27). ${ }^{32}$ However, the CRPD Committee has not clearly established if each of these conditions, on its own, is enough for a situation to qualify as a substitute decision making situation or there would have to be at least two for this to happen (Martin et. al., 2016, pp. 63-66).

In the Peruvian case, the provisions of articles $659-\mathrm{D}$ and $659-\mathrm{E}^{33}$ would match the first two elements mentioned. Applying these provisions would mean removing legal capacity and leaving the appointment in the hands of a judge, but the decisions will still be made based on the will and preferences of the person with disability. This means that, if the three conditions have to be cumulatively met in order for a regime to qualify as substitute decision-making, the Peruvian Reform has eliminated these. But if only one or two conditions have to be met in order for a situation to qualify as such, it is clear that the Peruvian Reform, and probably any future reform in the world, will keep substitute decision-making regimes. Under that interpretation, even emergency health care would

\footnotetext{
${ }^{32}$ See also: CRPD Committee. 2014. General comment No. 1 (2014) Article 12: Equal recognition before the law. Eleventh Session, 19 May 2014. Corrigendum on Paragraph 27. CRDP/C/GC/1/Corr.1.

${ }^{33}$ The provisions in the articles mentioned read as follows: "Article 659-D.- Designation of supports. The person of legal age who requires support for the exercise of their legal capacity can appoint their support before a notary or a competent judge."

"Artículo 659-E.- Exception for the judicial appointment of supports. A judge can, exceptionally, appoint the necessary supports for persons with disabilities who cannot manifest their will and for those persons with restricted juridical capacity, in conformity with article 44, numeral 9 . This measure will be justified after having placed real, considerable and pertinent efforts in place to obtain a manifestation of will from the person, having used measures of accessibility and reasonable adjustments, and when it is necessary for the exercise or protection of said person's rights.

The judge determines the person o persons to be appointed as supports considering the existing relationships of cohabitation, trust, friendship or parentage between the persons to be appointed and the person who needs supports. Likewise, the judge determines the term, reach and responsibilities of the supports. In all cases, the judge must adopt the necessary diligences to obtain the best possible interpretation of the will and the preferences of the person in question and consider their life trajectory. Persons who have been convicted of sexual or domestic violence cannot appointed as supports. The judicial process to appoint supports can exceptionally be initiated by any person with legal capacity." (Own translation).
} 
amount to substitute decision-making. As some have said, that approach is "too extreme" (Martin and Gurbai, 2019, p. 118) and, thus, inadmissible.

\section{SAfEguards IN THE Reform}

Safeguards are one of the least developed issues in legal capacity literature. Even the CRPD Committee's General Comment devoted only three paragraphs to this aspect (2019, para. 20-22). The Peruvian Decree defines safeguards as "measures to guarantee respect for the rights, will and preferences of the person receiving support, prevent abuse and undue influence on the part of the person providing such support as well as avoiding harm or putting at risk the rights of the persons assisted" (article 659-G, author's translation). On the other hand, CRPD's article 12.4 indicates that safeguards must ensure that supports "respect the rights, will and preferences of the person, are free of conflict of interest and undue influence". Table No. 1 sums up the differences between Article 12's provisions, and the terms of the Reform:

Table no. 1: Comparison between safeguards according to CRPD and the Peruvian reform Decree.

\begin{tabular}{|c|c|c|}
\hline Topic & $\begin{array}{c}\text { Safeguards according to } \\
\text { Article } 12.4\end{array}$ & Safeguards in the Reform \\
\hline Aim & $\begin{array}{l}\text { Prevent abuse in accordance with } \\
\text { international human rights law }\end{array}$ & "prevent abuse" (Art. 659-E) \\
\hline $\begin{array}{l}\text { Persons subject to } \\
\text { safeguards }\end{array}$ & Any person receiving support & $\begin{array}{c}\text { Can only be proposed by the } \\
\text { person receiving support or in the } \\
\text { case of judicially-mandated support } \\
\text { (Art. 659-E) }\end{array}$ \\
\hline $\begin{array}{l}\text { Limits to measures } \\
\text { relating to the } \\
\text { exercise of legal } \\
\text { capacity }\end{array}$ & $\begin{array}{l}\text { Respect the rights, will and } \\
\text { preferences of the person. }\end{array}$ & $\begin{array}{l}\text { Respect "for the rights, will and } \\
\text { preferences of the person receiving } \\
\text { support" (Art. 659-E) and "avoiding } \\
\text { harm or putting at risk the rights of the } \\
\text { persons assisted." (Art. 659-E) }\end{array}$ \\
\hline $\begin{array}{l}\text { Limits regarding } \\
\text { the person } \\
\text { providing the } \\
\text { support }\end{array}$ & $\begin{array}{l}\text { They have to be free of conflict of } \\
\text { interest and undue influence. }\end{array}$ & $\begin{array}{l}\text { Safeguards prevent undue influence } \\
\text { (Art. 659-E) } \\
\text { Persons convicted of family violence or } \\
\text { sexual violence cannot be supports }\end{array}$ \\
\hline Judicial limits & $\begin{array}{l}\text { Proportional and tailored to the } \\
\text { person's circumstances, apply for the } \\
\text { shortest time possible }\end{array}$ & At least time limits \\
\hline Judicial review & $\begin{array}{c}\text { Subject to regular review by } \\
\text { a competent, independent and } \\
\text { impartial authority or judicial body. }\end{array}$ & Judges review the safeguards \\
\hline$\overline{\text { Proportionality }}$ & $\begin{array}{l}\text { The safeguards shall be proportional } \\
\text { to the degree to which such measures } \\
\text { affect the person's rights and } \\
\text { interests. }\end{array}$ & No reference \\
\hline
\end{tabular}


One of the main differences has to do with the procedures through which safeguards are appointed. According to the Reform, judges can only impose safeguards on persons subject to the exceptional designation of supports by judges of the Article 659-E. That norm is designed only for when a person with a disability cannot express their will at all, so there is an evident need to designate a support. However, if the Peruvian Reform is to comply with international standards, safeguards should apply to any person receiving support. In the opinion of Martínez-Pujalte, the Peruvian Reform fails to adequately prevent "manipulation, abuse or undue influence" $(2019$, p. 18). Even though he recognizes this pitfall of the Reform, he argues that this is the "first regulation of legal capacity compliant with the Convention" (2019, p. 15). I have to disagree with this last point. Peru's regulation may be the regulation closest to compliance all around the globe, but if it does not comply with Article 12.4, then we cannot say that it is fully CRPD compliant.

Just recently, Legislative Decree 1384's Statute 016-2019-MIMP was enacted. ${ }^{34}$ This document provides little guidance on the application of the Reform. Regarding safeguards, there is an open-ended list of measures that can be taken like: providing accountability for the administration of property, audits, unexpected supervision, unexpected visits, hearings with the supporter or other persons close to the person receiving support and requiring information to public or private institutions (article 21). It does not seem as enough, especially if they can only be imposed in the exceptional cases. Additionally, these measures are ex-post. They do not prevent the abuse from happening. They may alert the judge about it. These creates two problems. First, safeguards should create ex-ante protections. This way, a support should be impeded to advise in transactions that may benefit her. A support should also have clear indications if she is going to make a manifestation of will: not selling under certain price, for example. The second problem that arises is that the ex-post measures do not specify how will they engage with juridical acts. If a judge notices an undue influence, there is no clear way if the juridical act can be nullified or not.

It is also important to note that one of the safeguards that has been imposed by the reform has to do with the history of the supporter. By virtue of article 659-E of the reformed Civil Code 1984, persons who have been convicted for family violence or sexual violence cannot be designated as supporters. ${ }^{35}$ This is inconsistent with the idea that anyone requesting supports has the right to choose the "form, identity, scope, duration and number of supports". ${ }^{36}$ In my opinion, however, a judge can validly limit

\footnotetext{
${ }^{34}$ The statute was enacted via Decreto Supremo 016-2019-MIMP, Decreto Supremo que aprueba el Reglamento que regula el otorgamiento de ajustes razonables, designación de apoyos e implementación de salvaguardias para el ejercicio de la capacidad jurídica de las personas con discapacidad, published on August $25^{\text {th }} 2019$.

${ }^{35}$ The relevant portion of the article reads as follows: "[...] Persons convicted of family violence or persons convicted of sexual violence cannot be designated as supporters. [...]". (Own translation).

${ }^{36}$ The relevant portion of the article reads as follows: "The person requesting the supports determines their form, identity, scope, duration and number of supports. The support can fall on one or more natural persons, public institutions or non-profit legal entities, specialized both in the matter and duly registered." (Own translation).
} 
said right. In many cases, the prohibition of persons convicted for family violence or sexual violence would be enough, but in other cases it will not be. One example would the case of persons convicted for embezzlement. In my opinion, the whole idea of safeguard seems to relate to a kind of paternalism that would be justified to avoid the abuse. This would allow the judge to decide who can and cannot be a provider of support. In any case, what will be necessary is for judges to develop a clear jurisprudence on how to implement these safeguards. This jurisprudence will have to consider the question that Piers Gooding posed: "How can the legal regulation of people's intimate lives be kept to an absolute minimum while still retaining effective safeguards against abuse?" (2013, p. 442).

\section{The Reform in current Private Law Theory}

The experience of the Reform was complicated because only a few Private Law academics or practitioners participated in the debate on legal capacity. ${ }^{37} \mathrm{I}$ think that many of them could not conceive an approach to supported decision making, but I also think that many of them failed to realize how article 12 and the legal capacity reform affect the traditional theory of the juridical act.

\subsection{The Juridical Act in Private Law}

In civil law jurisdictions, there is a general theory of the juridical act (Schmidt, 2012, p. 1016). According to private law doctrine, the essence of the juridical act is a "declaration by one or more parties intended to create a legal effect" (Schmidt, 2012, p. 1016). This theory encompasses any expression of will that creates a legal relationship: contract, marriage, will, recognition of child, etc. Thus, will is a key element in understanding all of private law in civil law jurisdictions.

However, will can be understood in different ways. According to "Savigny's will theory, the basis for the validity is the intention of the person making the declaration" (Schmidt, 2012, p. 1017). This means that if the intention was deficiently expressed (for any reason), the person cannot be bound by the declaration. This led to criticism, as it is dangerous when thinking about the level of legal certainty required for commercial affairs. On the other hand, the theory of declaration analyzes will based on the level of reliance provided by the person receiving the declaration. According to Oliver Wendell Holmes, "the making of a contract depends not on the agreement of two minds in one intention, but on the agreement of two sets of external signs - not on the parties' having meant the same things but on their having said the same thing" (1897, p. 7). As I will develop later, this theory can be of the utmost importance when dealing with the declaration of will of a person with disabilities. What should be taken into account when analyzing a contract? The real will of the person or the declaration that he or she made? And what effect does that have in persons with disabilities?

\footnotetext{
${ }^{37}$ One of the few examples I remember is an event at the Congress with the participation of professors Leysser León and Carlos Fernández Sessarego. See: (CONGRESO DE LA REPÚBLICA DE PERÚ, 2017)
} 


\subsection{Some examples of the interaction of the doctrine of juridical act and Article $\mathbf{1 2}$}

Academics have yet to analyze how the theory of juridical act will engage with the provisions of Article 12. For now, it is safe to say that a juridical act is an exercise of legal capacity and active legal capacity is the ability to exercise juridical acts. ${ }^{38}$ This ability needs to be inclusive to persons with disabilities. In the following pages, I offer a glimpse on what issues may arise and some proposals to overcome them.

\subsubsection{Error}

According to juridical act theory, when there is an essential error, there is no agreement, and therefore, there is no juridical act (Sefton-Green, 2005, p. 6). What would happen with this theory in cases regarding persons with disabilities? It is a fact that many legal theories were designed excluding persons with disabilities (Kittay, 2003). Nowadays, there is an urgent need to reassess those theories to make them disability inclusive, and to make them respond to the issues that will arise from implementing Article 12 compliant systems in civil law jurisdictions.

What is an error? According to Schermaier, at least in European continental jurisdictions, an error "enables the mistaken party to free himself from a given declaration of intent, a promise or a contract - provided certain conditions have been fulfilled" (SeftonGreen, 2005, p. 39). In Peru, in order for an error to make a contract voidable, it must be essential and must be recognizable by the other party. This can lead to complex situations with persons with disabilities.

Consider the following example: ${ }^{39}$ Jose has a mild intellectual disability and paranoia (usually not visible tor most people) and loves comic books and characters. He enters a comic book store, sees a golden gauntlet and exclaims "The Infinity Gauntlet!". He asks the salesperson if this is the real Infinity Gauntlet from the Marvel Comics. She says it is, because she thinks he is referring to whether it is a fake or an original piece. He decides to buy it, thinking it is the real Infinity Gauntlet. Later, he talks to his brother and realizes this is not a "real" Infinity Gauntlet. What is the correct legal response in this case, with regards both to private law theory and the social model of disability? Did the clerk have a duty to inform the customer that the product was not, stricto sensu, the literally real Infinity Gauntlet? Could she have known what Jose understood as "real"? Could Jose receive a refund for his purchase? In this situation, the debate between Savigny and Holmes's views becomes relevant. Which will would be relevant to the Law - the authentic will, or the declared will?

\footnotetext{
${ }^{38}$ This idea was proposed to me by Wayne Martin.

${ }^{39}$ I arrived at the idea for this hypothetical case with the input of Saulo Galicia.
} 
Let us add further difficulty to this case. Peru's Legislative Decree 1384 provides that supporters have to be registered in public records. ${ }^{40}$ This means that anybody will have access to this information. So, let us imagine that, in the case, the clerk notices the disability, reviews the public record and finds that this person has supporters. Is the person free to use them when he wants to? Can the clerk deny the sale on the grounds that the client has a support and require him to use it? This could be important if we consider that a mistake could lead to the annulment of the sale. For example, in the case of the proposed Reform to the Hungarian Civil Code (not in force), the support "shall attach his/her signature to a legal declaration to confirm that $\mathrm{s} /$ he was present at the making of such a legal statement, and he or she provided assistance [sic] the supported person". That would definitely be an imposition, but some might feel it is acceptable so long as it protects the validity of the agreement. In the same pace, the current Colombian Reform has also determined the need of the supporter to provide the support she was intended to give. However, the final decision remains in the person with disability. ${ }^{41}$

Actors in the legal system - lawyers, notaries, salesclerks or police officers - have few clues on what to do in cases of persons that need support. ${ }^{42}$ The UN CRPD Committee has stated that, in order to comply with Article 12, reforms must provide a "mechanism for third parties to challenge the action of a support person if they believe that the support person is not acting in accordance with the will and preferences of the person concerned" (2014, para. 29.d). In the Peruvian Reform, there is no provision on how third parties must act if they suspect a supporter is not correctly fulfilling his or her duties, much less a mechanism for them to challenge said actions.

On this topic, it is also important to acknowledge that notaries will have to make significant efforts to adapt their practice to the reform. Although notaries are not, stricto sensu, part of the juridical act, they do fulfill a crucial role in certifying the "capacity,

\footnotetext{
${ }^{40}$ The relevant article reads as follows: “Article 2030. Registered acts and resolutions.

Registered in this Registry are: [...] 1.- Resolutions or public deeds in which the designation of supports and safeguards of natural persons is established or modified. [...]

9. Resolutions that designate the guardian or the support and those that revoke them. [...]

${ }^{41}$ ARTICLE 19 of the Act 1996 of 2019 . Support agreements as a requirement for the validity of juridical acts.

The person entitled to perform a juridical act with a valid and current support agreement for the celebration of specific juridical acts, must use the designated supports when celebrating the act, as a requirement of its validity.

In consequence, if the person entitled to perform the juridical acts carries out the juridical acts specified in the support agreement, without using the stipulated supports, this will be cause for relative invalidity of the act, following the general rules of the civil legal regime.

PARAGRAPH. The above disposition cannot be interpreted as an obligation of the person entitled to perform a juridical act to act according to the will of the person or persons providing support. In accordance to article 4, numeral 3 of this Law, supports must respect the will and preferences of the person entitled to perform the juridical act, as well as respect their right to take risks and make mistakes.

${ }^{42}$ It is important to note that CRPD Article 13(2) reads as follows: "In order to help to ensure effective access to justice for persons with disabilities, States Parties shall promote appropriate training for those working in the field of administration of justice, including police and prison staff."
} 
freedom and knowledge" of the parties to the act (Article 54.h of Notary Act, Legislative Decree 1049 2008). It is not clear how notaries will address the abilities of a person with disability in this new context. Nowadays, capacity cannot be grounds for the denial of the act of a person with a disability. But following this premise, how should we assess freedom to choose? What happens if a notary suspects that a person with disability is acting under undue influence? Should they refuse to certify the act? What would the consequences be? I will explore some of these situations in the 'undue influence' section of this document.

As mentioned before, we need to reassess every general theory of the law in light of the social model of disability. By disregarding the functional approach for granting legal capacity, the CRPD Committee has disregarded some traditional tenets of private law. Even though we may disagree with the premise, many legal institutions work on the presumption of a certain "regular" brain functionality. The doctrine of error is useful insofar as it allows a person to distance herself from something "they may not have intended" (Series, 2014).

\subsubsection{Conflict of interest}

Article 12.4's standard creates a significant problem when assessing CRPD compliance of the Peruvian reform, because the Decree does not include any provisions with regards to "conflict of interest". I hold that a conflict of interest happens as a given situation when a person's interest may interfere with their duties (Martin et. al., 2016, p. 49). Usually, lawyers are tempted to solve conflict of interest by eliminating or disclosing them. However, that is not the standard of Article 12.4. In fact, if we follow Article 12.4, the supporter's duty should be to manage the conflict of interest, not so to avoid it (Martin et. al., 2016, p. 49).

How can we ensure that the supporters are "free of conflict of interest", when they are usually close to the person with a disability? Let us present an example: Barbara has a mild intellectual disability and appoints her mother as her support. She does not think of any need for safeguard, especially because she is not quite sure about their necessity or convenience. However, a few months later she opens a bank account and the clerk offers her the possibility to sign an insurance contract in favor of a third party. When she asks what this means exactly, the clerk says it will give money to a person of her choice if something happens to her. Later on, she decides that she wants to write her will, so she goes to a notary. In Peru, the Civil Code 1974 requires a witness to the will, who cannot also be a beneficiary of the will. Barbara wants to leave her mother some money.

In both cases, regarding the insurance and the will, can Barbara's mother be her supporter? Article12.4 would seem to indicate that she could not be a supporter in these situations. The Decree says that safeguards only applies if a person asks for them, which makes no sense regarding the obligations of Article 12.4. Now, if a judge has not established any safeguards regarding conflict of interest, what should the clerk or the notary do?

Using the Decree, what should they do if they believe that the conflict of interest has led to abuse or undue influence? In this particular case, the Decree seems to not comply adequately with the standard of Article 12.4. Then again, there are no clear instructions 
for the legal community on how to deal with the situation when they detect a support not working as it should. For example, using the previous example: under what circumstances would the clerk have to act?

One standard could be that a clerk - or any third party- has to act "in any situation that arises a conflict of interest". That could create extreme difficulties for persons with disabilities in signing contracts, because supports are usually relatives or close friends. Another possibility is that the sole existence of the conflict of interest creates the duty of the third party to act. We could construct a two-fold standard: A third party has the duty to avoid the juridical act when the support of the person with disability has a conflict of interest and the decision seems to create an unfair advantage for the supporter that goes against the rights of the person with a disability. In the previous case, the conflict of interest would be irrelevant as it does not affect Barbara's rights.

\subsubsection{Undue influence}

Common law has best developed the concept of undue influence. According to common law doctrine, undue influence is the use of any act of persuasion in order to overcome the free will and the judgment of another person (Lehman and Phelps, 2005). California statutory law provides three elements to be considered regarding undue influence: (i) vulnerability of the victim, (ii) the influencer's apparent authority, (iii) the actions or tactics used by the influencer and (iv) the equity of the result (Section 15610.70 of the Welfare and Institutions Code of California).

I will propose another example that demonstrates the difficulty in addressing this issue. Marina is person with a mild intellectual disability. She has two brothers: Alan and Hugo. Hugo has two children. Both Alan and Hugo are supports for Marina. However, Marina talks to Hugo more often because she lives near his house. One day, Hugo encourages Marina to write a will, telling her that it would be really useful for his children (her niece and nephew) if she could leave things for them. She likes this idea and asks if he knows any lawyer who could help. Hugo hires a lawyer and Marina writes a will benefiting Hugo's children. The will explicitly states: "I came up with the idea of leaving all my things to my niece and nephew when my brother told me how useful that would be for their education". When Alan finds out, after Marina passes away, he seeks the nullification of the will. Should his claim be successful?

Two problems come to mind when dealing with this situation. The first one has to with identifying situations that would amount to undue influence, and when undue influence should be grounds for an annulment or nullification of the juridical act. I propose that, in order to ask for a nullification, two criteria must be met: there has to be undue influence and such undue influence must damage the rights of the person. ${ }^{43}$ I base this proposal on the case of Strickland v. Washington. ${ }^{44}$ In that case, the United States Supreme Court held that a defendant would have to establish two propositions to

\footnotetext{
${ }^{43}$ This idea arose in conversation with Robert Dinerstein.

${ }^{44}$ Strickland v. Washington, 466 U.S. 668 (1984).
} 
demonstrate that legal counsel had been so defective that it would amount to ineffective assistance of counsel. According to the US Supreme Court, "First, the defendant must show that counsel's performance was deficient. [...] Second, the defendant must show that the deficient performance prejudiced the defense" (1984, para. 687). For our case, I would argue that, in order for undue influence to be a ground for annulment it has to meet two criteria: First, there has to be an undue influence that vitiates the real will of the person. Second, there has to be an actual damage to the rights of the person with disabilities. This would comply with the idea of Article 12.4. The first criterion protects the will and preferences, the second one, rights.

For the first criterion, I will use what George Szmukler called the "spectrum of treatment pressures" (2018, p. 151). Even though they were originally designed for treatment, I find them quite useful for these situations. The spectrum includes persuasion, interpersonal leverage, inducement, threats and compulsion. Compulsion and threats would be ground for the nullification of the juridical act by themselves, so it is not necessary to address them regarding undue influence. However, the three remaining items need to be carefully analyzed.

Persuasion goes beyond the mere facts and tries to "appeal to reason (and to some degree to the emotions)" (Szmukler, 2018, p. 154). However, it is also a part of common human relationships. We usually want to convince others around us that what we think is right and they should follow our advice. Thus, I would argue that, prima facie, persuasion would not amount to undue influence, but that that may change if persuasive techniques are applied constantly and consistently. In the case presented, persuasion was what Hugo used to convince Marina. However, that action does not seem like an imposition of Hugo's will over Marina's.

The situation would be much different if Hugo had had a plan to convince her and would try to impose this idea every time he saw Marina. Interpersonal leverage means using a relationship as a source of pressure (Szmukler, 2018, p. 155). Comments such as "if you don't do this, I will be very sad" and actions that reflect the same intent would amount to interpersonal leverage. Once again, prima facie, this does not look like undue influence by itself. However, if comments like these are made on a regular basis, they certainly might amount to it. Finally, offers or inducements would be considered a form of undue influence, since they do not reflect the real will of the person. Of course, this is open for discussion. Persons without disabilities change their opinions all the time.

The second step would be to analyze whether or not there was any damage. In the case of Marina (and any other last will case), there is no ground for annulment. Whoever she had chosen as an heir made no difference to her rights, since the transfer of goods happens postmortem. Therefore, none of her rights are affected.

\subsection{Preliminary conclusions}

Both undue influence and conflict of interest raise the question of when should that be grounds for a request to nullify a will or a contract? I have provided some guidelines 
when those situations arise. For these situations, Private Law has to change to adapt to the recognition of legal capacity of persons with disabilities. This recognition cannot be understood as an opportunity to "abandon or ignore people with disabilities who may be vulnerable to violence, abuse and exploitation" (Arstein-Kerslake and Flynn, 2016, p. 479). It has to be understood as an opportunity change the current understanding of certain core issues in Private Law, like the concept of will. That exercise also has to include the creation of safeguards that protect the person from different situations. Some of them will be an expansion of previous institutions, like the error. But some others may be new figures that need to be drafted in a way that is coherent with the rest of Private Law. That is the case of undue influence and conflicts of interest.

\section{Conclusions}

As others have stated, the journey of legal capacity of persons with disabilities has just begun (Arstein-Kerslake and Flynn, 2016, p. 471). There is no clear map, but we know we have a goal. So, we have to give it a try. States are trying to change their laws, but this process is quite difficult. There are no clear guidelines on how to reform a Civil Code 1984. Lawyers who specialize in Private Law (property, contracts and torts) are usually not keen to have a dialogue with human rights or disability lawyers. Many judges and notaries are against the recognition of legal capacity of persons with disabilities. ${ }^{45}$

But, against all odds, reforms happen. And it happened in Peru. I was a privileged witness to the process. I have been able to talk to judges, notaries, activists, relatives of persons with disabilities, academics and policy makers on this issue. I believe we need to be proud of this advancement. However, as academics, we have the urge to provide a coherent framework for understanding. That is something we need to come up with. Academics are trying to deliver disability-neutral understandings for consent (Brosnan and Flynn, 2017), State intervention (Flynn \& Arstein-Kerslake, 2017; Gooding \& Flynn, 2015)) and care and autonomy (Feder Kittay, 2005, p. 8). Lawyers and academics from the Civil Law (Continental) tradition need to think about how the recognition of the legal capacity of persons with disability and the provision of support alter our view on the juridical act. We need to create a new understanding for will in our legal system that allows people with disabilities to marry, sign contracts, make a will or be part of an association. But that same understanding must enable people with disabilities to claim they made a mistake or that their will was coerced or under undue influence.

Finally, there is a crucial role for judges. They will be the ones in charge of drawing lines and applying the provisions of the Reform. They will also be in charge of filling in the gaps they may find in the legislation. It is important to note that, in some other jurisdictions, judges have understood supports as a new name for guardian (Iglesias Frecha, 2017). Therefore, there must be a public policy on how to apply the Reform, how to solve the issues that were not addressed in the legislation and on how to evaluate its implementation. Finally, I would like to recall that, around a hundred years ago, André

\footnotetext{
${ }^{45}$ I cannot provide specific data for this statement. However, I have participated in at least eight training sessions for judges. The auditorium is usually filled with critics of the reform.
} 
Breton said: "It is not the fear of madness which will oblige us to leave the flag of imagination furled" (Breton, 1972). We need to embrace that feeling. The consequences of the inclusion of madness and disability in Private Law are not to be feared. They should help us reframe our understanding of our will, our vulnerability and our humanity.

\section{REFERENCES}

ARSTEIN-KERSLAKE, A. and Flynn, E. (2016) The General Comment on Article 12 of the Convention on the Rights of Persons wth Disabilities: A Roadmap for Equality before the Law. The International Journal of Human Rights, 20(3), 471-90. https:// doi.org/10.1080/13642987.2015.1107052 (Last accessed on October 10th, 2019).

BOLAÑOS SALAZAR, E. R. (2018) La Reforma Del Régimen Peruano de Interdicción de Personas Con Discapacidad Mental y Psicosocial Desde La Perspectiva de Los Derechos Humanos. Thesis to obtain a JD equivalent. Lima: Universidad San Martín de Porres. https://bit.ly/331SxAz

BREGAGLIO LAZARTE, R. A., \& Constantino Caycho, R. A. (2020). Un modelo para armar: La regulación de la capacidad jurídica de las personas con discapacidad en el Perú a partir del Decreto Legislativo 1384. Revista Latinoamericana en Discapacidad, Sociedad y Derechos Humanos, 4, 28.

BRETON, A. (1972) Manifestoes of Surrealism. 1st edn. as an Ann Arbor paperback. Ann Arbor Paperbacks 182. Ann Arbor, Mich.: University of Michigan Press.

BROSNAN, L, and Eilionóir F. (2017). Freedom to Negotiate: A Proposal Extricating 'Capacity' from 'Consent'. International Journal of Law in Context 13(1), 5876. https://doi.org/10.1017/S1744552316000471 (Last accessed on October 10th, 2019).

CASTILlO FREYRE, M. (2005). El defectuoso anteproyecto de reforma al Código Civil y las Personas Naturales, online: Estudio Mario Castillo Freyre $<$ https:// www.castillofreyre.com/archivos/pdfs/articulos/las_personas_naturales_y_el_ anteproyecto.pdf $>$.

COMMITTEE ON THE RIGHTS OF PERSONS WITH DISABILITIES (2014) General Comment No. 1 (2014) Article 12: Equal Recognition before the Law. $C R P D / C / G C / 1$.

CONGRESO DE LA REPÚBLICA DE PERÚ. (2017). Análisis de proyectos de ley que modifican el Código Civil en materia de capacidad jurídica de personas con discapacidad. 6 October, 2017. http://www2.congreso.gob.pe/Sicr/Prensa/heraldo. nsf/00NoticiasArchivo/8455a4f6e95f2555052581b1006a8c72/?OpenDocument

DAVID, R. (1968/1978) Major Legal Systems in the World Today: An Introduction to the Comparative Study of Law. Translated by John E. C. Brierley. 2nd edn. New York, New York: Free Press.

DAWSON, J. (2015). A Realistic Approach to Assessing Mental Health Laws' Compliance with the UNCRPD. International Journal of Law and Psychiatry 40, 70-79. https:// doi.org/10.1016/j.ijlp.2015.04.003 (Last accessed on October 10th, 2019). 
DE BHAILÍS, C., \& Flynn, E. (2017). Recognising legal capacity: Commentary and analysis of Article 12 CRPD. International Journal of Law in Context, 13(01), 6-21. https://doi.org/10.1017/S174455231600046X

DEL VILLAR, K. (2015). Should Supported Decision-Making Replace Substituted Decision-Making? The Convention on the Rights of Persons with Disabilities and Coercive Treatment under Queensland's Mental Health Act 2000. Laws 4(2), 173-200. https://doi.org/10.3390/laws4020173. (Last accessed on October 10th, 2019).

DEVANDAS, C. (2017). Report of the Special Rapporteur on the rights of persons with disabilities. A/HRC/37/56.

DHANDA, A. (2017). Conversations between the proponents of the new paradigm of legal capacity. International Journal of Law in Context, 13(01), 87-95. https://doi. org/10.1017/S1744552316000501

DINERSTEIN, R. D. (2012). Implementing Legal Capacity Under Article 12 of the UN Convention on the Rights of Persons with Disabilities: The Difficult Road From Guardianship to Supported Decision-Making. Human Rights Brief 19(2), 8-12.

DINERSTEIN, R; Grewal, E and Martinis, J (2016). Emerging International Trends and Practices in Guardianship Law for People with Disabilities. ILSA Journal of International \& Comparative Law 22(2), 436-460. https://works.bepress.com/ robert-dinerstein/1/ (Last accessed on October 10th, 2019).

FLYNN, E. and Arstein-Kerslake, A. (2017). State Intervention in the Lives of People swith Disabilities: The Case for a Disability-Neutral Framework. International Journal of Law in Context 13(1), 39-57. https://doi.org/10.1017/S1744552316000495 (Last accessed on October 10th, 2019).

GOODING, P. (2013). Supported Decision-Making: A Rights-Based Disability Concept and Its Implications for Mental Health Law. Psychiatry, Psychology and Law 20(3), 431-451. https://doi.org/10.1080/13218719.2012.711683 (Last accessed on October 10th, 2019).

GOODING, P and Flynn, E. (2015). Querying the Call to Introduce Mental Capacity Testing to Mental Health Law: Does the Doctrine of Necessity Provide an Alternative? Laws 4(2), 245-271. https://doi.org/10.3390/laws4020245 (Last accessed on October 10th, 2019).

HOFFMAN, I.; and Könczei, G. (2010). Legal Regulations Relating to the Passive and Active Legal Capacity of Persons with Intellectual and Psychosocial Disabilities in Light of the Convention on the Rights of Persons with Disabilities and the Impending Reform of the Hungarian Civil Code. Loy. L.A. Int'l \& Comp. L. Rev 33(1), 143-173.

HOLMES, O. W. (1897). The Path of the Law. Harvard Law Review 10(8), 457-478. 
IGLESIAS FRECHA, J. M. (2017). 'Discursos Jurídicos En Torno a Los Apoyos Para Ejercicio de La Capacidad Jurídica y La Vida Independiente en 2017 ¿Qué Dicen Las/Os Jueces de La Ciudad Autónoma de Buenos Aires En Sus Fallos?', VI Jornadas Nacionales Discapacidad y Derechos, Neuquén, Argentina, 14-15 june.

KITTAY, E. F. (2005). 'Equality, Dignity, and Disability.' In Lyonns M Ann and Fionnuala Waldron (eds) Perspectives on Equality. The Second Seamus Heaney Lectures. Dublin: The Liffey Press, 93-119.

KITTAY, E. F. (2005). Equality, Dignity, and Disability. In M. A. Lyons \& F. Waldron (Eds.), Perspectives on Equality The Second Seamus Heaney Lectures (p. 28). The Liffey Press.

LEHMAN, J. and Shirelle P. (eds) (1998/2005). West's Encyclopedia of American Law. 2nd ed. Detroit: Thomson/Gale.

MARTIN, W. and Gurbai, S. (2019). Surveying the Geneva Impasse: Coercive Care and Human Rights. International Journal of Law and Psychiatry, 64, 117-28. https:// doi.org/10.1016/j.ijlp.2019.03.001 (Last accessed on October 10th, 2019).

MARTIN, W; Michalowski, S; Stavert, J; Ward, A; Ruck Keene, A; Caughey, C; Hempsey, A and Mcgregor, R (2016). Three Jurisdictions Report. Towards Compliance with CRPD Art. 12 in Capacity/Incapacity Legislation across the UK. Essex: Essex Autonomy Project. https://autonomy.essex.ac.uk/wp-content/uploads/2017/01/ EAP-3J-Final-Report-2016.pdf (Last accessed on October 10th,2019).

MARTINEZ-PUJALTE, A. (2019). Legal Capacity and Supported Decision-Making: Lessons from Some Recent Legal Reforms. Laws 8(1), 4, 1-22. https://doi. org/10.3390/laws8010004 (Last accessed on October 10th, 2019).

MINKOWITZ, T. (2017). CRPD and transformative equality. International Journal of Law in Context, 13(01), 77-86. https://doi.org/10.1017/S1744552316000483

MINKOWITZ, T. (2018). Peruvian Legal Capacity Reform - Celebration and Analysis. [Blog]. Mad in America. https://www.madinamerica.com/2018/10/peruvian-legalcapacity-reform-celebration-and-analysis (Last accessed on October 10th, 2019).

SCHMIDT, J. P. (2012). 'Juridical Act'. In “Juridical Act.” In Jürgen Basedow, Klaus J. Hopt, and Reinhard Zimmermann (eds) The Max Planck Encyclopedia of European Private Law, edited by. Oxford: Oxford University Press.

SEFTON-GREEN, R. (2005). Mistake, fraud and duties to inform in European contact law. Cambridge University Press.

SERIES, L. (2014). Submission to the Committee on the Rights of Personas with Disabilities. Available at: https://www.ohchr.org/EN/HRBodies/CRPD/Pages/ DGCArticles12And9.aspx

SZMUKLER, G. and Bach, M. (2015). Mental Health Disabilities and Human Rights Protections. Global Mental Health 2(e20), 1-9. https://doi.org/10.1017/ gmh.2015.18 (Last accessed on October 10th, 2019). 
SZMUKLER, G. (2018). Men in white coats: Treatment under coercion. (First edition). Oxford University Press.

VERANO, C. Constantino, R and Bregaglio, R. (2018). Selección de jurisprudencia del Tribunal Constitucional del Perú en materia de discapacidad desde la entrada en vigor de la Convención sobre los Derechos de las Personas con Discapacidad. Revista Latinoamericana en Discapacidad, Sociedad y Derechos Humanos 2, 185-204. http://redcdpd.net/revista/index.php/revista/article/download/120/67 (Last accessed on October 10th, 2019).

Received: January $31^{\text {st }} 2020$

Accepted: April 12 2020 